\title{
A new variety of Hibiscus hirtus (Malvaceae), from Maharashtra, India
}

\author{
Suchandra Dutta1*, Hensal Rodrigues ${ }^{2}$ and Kiran Chakral ${ }^{2}$ \\ ${ }^{1}$ Department of Botany, R.D. \& S.H. National College Seth W.A. Science College \\ Bandra (W), Mumbai, Maharashtra - 400 050, India \\ ${ }^{2}$ Department of Btany, Viva College, Virar, Maharashtra, India \\ *E-mail: suchandra.dutta@gmail.com
}

\begin{abstract}
Hibiscus hirtus L. var. inarticulatus (Malvaceae), a new variety is described and illustrated from India. It differs from the typical form and $H$. hirtus var. talbotii in having 3-lobed lower leaves, lanceolate upper leaves and in the absence of articulation in the pedicels.
\end{abstract}

Keywords: Hibiscus hirtus var. inarticulatus, Maharashtra, new variety, Sanjay Gandhi National Park

\section{Introduction}

While studying the floristic diversity of Sanjay Gandhi National Park, Mumbai in Maharsahtra, the authors collected an interesting specimen of Hibiscus sect. Bombicella, resembling H. hirtus L. var. talbotii Rakshit. Critical studies in comparison with relevant types and protologues revealed it to be a new variety of $H$. hirtus L., which is described here.

Hibiscus hirtus L. var. inarticulatus S. Dutta, H. Rodrigues \& Kiran Chakral, var. nov. $\quad$ Fig. 1.

Similar to $H$. hirtus var. talbotii but differs in having ovate, 3-lobed lower leaves (opposed to ovatelanceolate, unlobed in var. talbotii), lanceolate upper leaves (opposed to ovate in var. talbotii) and in the absence of an articulation in the pedicel.

Type: INDIA, Maharashtra, Mumbai, Sanjay Gandhi National Park, January 2015, SD/HR/KC 1501 (Holotype, CAL; Isotypes, CALI, R.D. \& S.H. National College Herbarium, Mumbai).

Subshrubs to $1.5 \mathrm{~m}$ tall. Stems terete, pubescent with stellate hairs intermixed with simple hairs; Lower leaves ovate, 3-lobed, upper ones lanceolate, $5.7-12.3 \times 1.2-4.7 \mathrm{~cm}$; venation multicostate, 3-5-nerved from base with a linear nectary at the base of the midrib beneath; petiole up to $3.2 \mathrm{~cm}$ long; stipules linear. Flowers axillary, solitary; pedicels $1.2-.3 \mathrm{~cm}$ long, shorter than petioles, inarticulate; involucellar bracts $6-7$, shorter than calyx, linear-lanceolate, calyx 5-fid; petals 5, white, rounded at apex; staminal column $1.1 \mathrm{~cm}$ long, shorter than petals, toothed, bent towards oneside, antheriferous throughout; anthers reniform, dense towards apex; pollen globose, panporate; ovary subglobose; stigmas five, capitate. Capsules sub-globose, young ones longitudinally 5-striped, slightly puberulous. Seeds 1 or 2 per cell, reniform, densely clothed with long, silky hairs.

Flowering \& fruiting: December - April.

Habitat: Open areas in deciduous forests.

Etymology: The varietal epithet refers to the inarticulate nature of the pedicel of this taxon.

Key to the varieties of Hibiscus hirtus

1. Pedicel not articulated

Hibiscus hirtus var. inarticulatus

1. Pedicel articulated ................................................ 2

2. Corolla brick red; pedicel articulated at or below the middle ............... Hibiscus hirtus var. hirtus

2. Corolla red, white or orange; pedicel articulated above the middle Hibiscus hirtus var. talbotii

Note: Hibiscus hirtus was originally described by Linnaeus (1753) as "Planta parva.... Caulis et calyces sutus pilis rigidiusculis hirta. Folis lanceolata, angusteserrata corolla purpurea" based on a specimen 


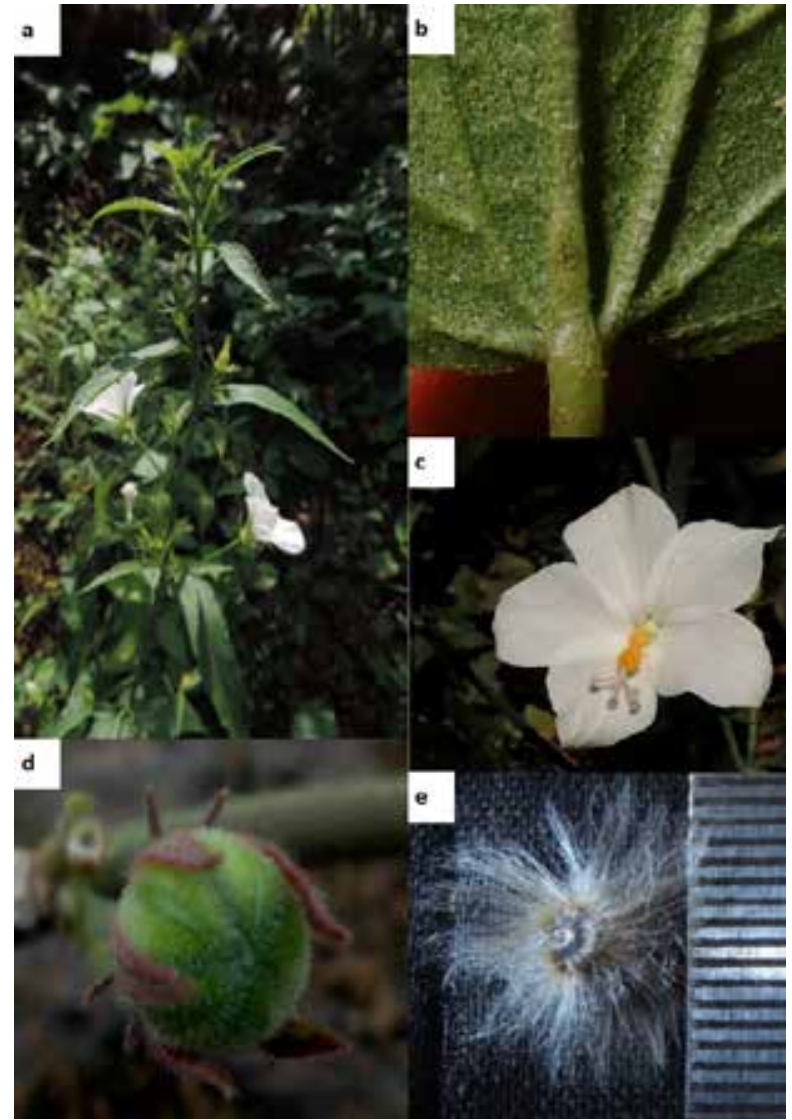

Fig. 1. Hibiscus hirtus L. var. inarticulatus: a. Flowering twig; b. Basal part of abaxial leaf surface showing nectar glands; c. Flower; d. Capsule; e. Seed.

(Linn.n. 675.18) from India. Though the species is well defined, the Linnaean protologue is too generalized to be helpful in determining the identification. An examination of the type reveals its pedicel articulated, the articulation is much above the middle (4- $4.5 \mathrm{~mm}$ below the flower) and the pedicel is thicker than the peduncle. Though the flower colour was mentioned as purple in the protologue, the variants with pure white corolla are not unusual in Hibiscus sect. Bombicella.

Rakshit and Kundu (1961) described the variety $H$. hirtus L. var. talbotii from western India. Subsequently, Paul and Nayar (1980) elevated its status to the rank of a species, $H$. talbotii (Rakshit) T.K. Paul \& M.P. Nayar. This view was also followed by Sivarajan and Pradeep (1991). The authors however prefer to keep it as a variety of Hibiscus hirtus L.

\section{Acknowledgements}

The authors thank Dr. K.N. Gandhi (Senior Nomenclature Registrar, Harvard University, USA) and Dr. A.K. Pradeep (Department of Botany, Calicut University) for guidance and help; Dr. Subir Bandopadhay (Central National Herbarium, Kolkata) for help in procuring the type material and literature; Greenline for financial support; Principal, R.D. \& S.H. National College, Dr. Vibha Mehra, Head, Department of Botany, R.D. National College and Dr. Behnaz Patel, Former Head, Department of Botany, Ramnain Ruia College for encouragement and support to conduct the laboratory work during this project.

\section{Literature Cited}

Linnaeus, C. 1753. Species Plantarum Laurentius Salvius, Sweden.

Paul, T.K. \& M.P. Nayar 1980. Notes on Hibiscus hirtus L. and Hibiscus talbotii (Rakshit) T.K. Paul \& M.P. Nayar. Bull. Bot. Surv. India 22: 197- 194.

Rakshit, S.C. \& B.C. Kundu 1961. New species and varieties of Hibiscus. Science $\mathcal{E}$ Culture 27: 192-194.

Sivarajan,V.V. \& A.K. Pradeep 1996. Malvaceae of southern Peninsular India: A taxonomic monograph. Daya Publishing House, New Delhi.

Received: 23.03.2016

Revised and Accepted: 19.06.2018 